\title{
How Leadership Styles Influence Commitment to Service Quality (CSQ): A Case Study of Hospitals of Sindh Pakistan
}

\author{
Munwar Hussain Pahi ${ }^{1}$ \\ Dr. Kamal Ab. Hamid² \\ ${ }^{1}$ PhD Scholar, University Utara Malaysia; hussainpahi@gmail.com \\ 2Associate Professor, University Utara Malaysia; abkamal@uum.edu.my
}

\section{Doi:10.5901/mjss.2015.v6n6s2p282}

\begin{abstract}
The present study investigates the effect of transformational, transactional and laissez-fair leadership styles on commitment to service quality and a cross sectional study was used to examine the relationship. The study utilized a quantitative research design Self-administered questionnaires were distributed to respondents. Three hundred and seventeen questionnaires were received from medical staff (doctors) of 43 hospitals from the province of Sindh, Pakistan. The data was analyzed using Smart PLS 2.0 software. The results of the study indicate that transformational and transactional leadership styles have positive relationship with commitment to service whereas laissez-fair style of leadership has no significant relationship with commitment to service quality. In the last part of the paper results and implications are discussed.
\end{abstract}

Keywords: CSQ, transformational leadership, transactional Leadership, Laissez-Fair

\section{Introduction}

In service organization behavior of employees play vital role regarding the customer perceptions to satisfaction and service quality perspective (Bitner, Booms \& Tetreault, 1990; Sergeant and Frenlel 2000). Evidence that boundaryspanning personnel communication directly with customer as most important part of service encounter. Additionally scholar defined that when service delivered to customer where interaction between employee and customer that behavior of services delivering of front line employees impact on service receiver. The key issue in the service sector is the attitudes of direct service providing employees, who regularly meet their customers and deliver services on daily basis (Bowen, Siehl \& Schneider, 1989) furthermore service organization, face the issues in attitude of employees (Bowen and Schneider, 1988). That attitude and guideline to provide services to customers is referred as CSQ (Peccei \& Rosenthal, 1997).Commitment of employees consider most important in service organization which positively effects clients perception (George \& Gronroos, 1989 Bitner, Booms \& Tetreault, 1990; Sergeant \& Frenlel, 2000). Employee commitment to service quality (CSQ) Permit to front line employees to treat effectively with dissatisfied clients and which in turn, employee to sustain a positive relationship with the firm (Sun et al., 2012).

Commitment to service quality as same footpath general definition of affective commitment. Affective commitment is defined by Meyer and Allen (1991) from organization commitment as "an employee"s emotional attachment to, identification with and involvement in the organization". CSQ is following the same path which related to individual attitude toward commitment to service quality.

Previous research provide the evidence that CSQ is important in ensuring excellent service quality (Hartline, Maxham \& Mckee, 2000; Babakus, Yavas, Karatepe \& Avci, 2003; Elmadag, Ellinger \& Franke, 2008; Clark, Hartline \& Jones, 2009) CSQ has gotten sufficient consideration from various researchers. However, past literature had not provided enough proof to account for fluctuating responses of internal employees about service and did not take initiatives customer service in organization for delivery of service (Peccei and Rosenthal, 2000). According to Peccei and Rosenthal (1997) and Worsfold (1999) who discovered that there is not much attention given to employees' CSQ, especially in the service business, particularly when the concern is on continuous improvement customer expectations (Hartline et al., 2000).

Previous studies are providing enough evidence that leadership has been under investigation with service quality (Krantz, 1989; Deming, 1986; Cole et al., 1993; Juran, 1989; Ebrahimpour, 1985; Lascelles and Dale, 1989; Dale and Duncalf, 1984). However, the relationship between CSQ and leadership styles has been ignored for further investigation. 
Furthermore previous studies on CSQ were also limited in terms of studying the CSQ at management level (Reeves \& Hoy, 1993; Hartline \& Ferell, 1996;Babakus et al., 2003; Hartline, 2000; Ashill, Ragheb, Abd-El-Salam, \& ElSamadicy, 2014; Malhorta \& Mukherjee, 2004; Ghorbani, Alemorad \& Bojnord, 2013) and (Subramony, Beehr \& Johnson, 2004; Ashill,Carruthers \& Krisjanous, 2006; Little \& Dean, 2006; Barnett, Tavitiyaman \& Kim, 2009; To Martin, \& Billy, 2015). Karatepe, \& Karadas, $2012 \mathrm{Lau}, 2014)$. None of studies have focused on the CSQ from employee perspective. The investigation of the CSQ with leadership styles has also been limited. Studies also emphasize the need for examination of the relationship between CSQ and leadership styles (Hashim \& Mahmood, 2012; Natasha \& Sbroto, 2003). According to many, leadership mechanism might help to overcome this situation as it helps in envision the goal and hence providing the climate and resources which will direct them towards a continued CSQ (Hartline et al., 2000; Hashim \& Mahmood, 2012; Natasha and Subroto 2003; Clark et al., 2009).

Nawaz and Bodla (2010) conducted research in education sector and recommended leadership style for future research in hospital. Hashim and Mohmmood (2012) studied CSQ in the education sector and suggested further examination into the hospital sector. Due to the following reasons, the CSQ-Leadership style relationship has been proposed in this study. First, the past literature, as witnessed above, has been emphasizing on service quality and leadership style(s). Second, the literature also suggest that management CSQ has been thoroughly investigated and reported though, leadership concern still remains ignored. Third, the studies that applied CSQ have been conducted into the educational and other sectors ignoring the health sectors. Fourth, most of the these studies have been produced in the UK, Turkey, Canada and the US and there is little evidence available on the investigation of this phenomena in the hospital sectors in Pakistan, hence this study will look into the relationship between CSQ and leadership style in the hospitals in Sindh, Pakistan.

\section{Literature Review}

\subsection{Leadership and CSQ}

Leadership refers to setting the direction or developing vision along with strategies that are necessary to produce the changes which are required for achieving a goal (Long \& Thean, 2011). Furthermore researchers described that leadership style is a procedure of communication of a leader who attempts to impact his or her followers to achieve a common objective (Yukl, 2005 \& Northouse, 2010). Role of leadership defined by many authors success of quality initiative has been highlighted (Krantz, 1989; Juran, 1989 Deming, 1986; Lascelles \& Dale, 1998; Cole et al., 1993; Ebrahimpour, 1985). Yet, little research has been conducted to investigate the leadership styles that support quality implementation. According to (Clark et al., 2009; Liao \& Chuang, 2007; Emery \& Barker, 2007; Erkutlu, 2006; Barnett, McCormick \& Conners, 2001) leaders have mission, vision, ability to motivate and engage staff in CSQ.

According to (Hashim \& Mahmood, 2012) the role of leadership is to create an environment that can change employee attitude towards CSQ. Similarly, Wallace et al., (2013) stated that the leadership can encourage employees towards commitment. The argument is supported by (Mitchell, 2002) stating that employees are more committed in organizations when reinforced by the leadership. Hence, it is imperative to study the role of leadership styles to booster employee CSQ. Further, the present research will address this issue in the hospital settings in Pakistan as according to (Hashim \& Mahmood, 2012) more research is required to be conducted on the said relationship in hospital settings. A rigorous literature review on how leadership styles are related with CSQ is presented below.

\subsection{Transformational Leadership and CSQ}

Research on transformational leadership has been very common throughout the previous two decades. There is enough proof to confirm that transformational leadership boost employee attitude toward commitment and performance (Bass, 199; Lowe et al., 1996, and Clark, 2009).

In a study Clark et al., (2009) researched conducted in hotel industry involving the hotel employees to found that transformational leadership is more influence than other leadership styles for enhancing CSQ. It also enhances employees' satisfaction and commitment to their organization (Barling et al., 2000; Hater and Bass, 1988). Transformational leader is known to generate a strong sense of commitment from their employees. This has resulted in the increase of productivity and performance in organizations (Eunyoung, 2007; Wang \& lawler, 2005; Walumbwa). According to Geijsel et al., (2003) the vision building of transformational leaders has demonstrated a strong influence on followers' commitment to change, since individuals are allowed to participate in decision making. These impacts of transformational leadership have been deemed as positive in the past. Studies, like those published by Emery and Barker 
(2007); Erkutlu (2006); Barnett, et al., (2001); and Liao and Chuang (2007) support the viewpoint that transformational leadership affects the subordinates' commitment. For example, a study by Erkutlu (2006) based on a boutique hotel in Turkey, result that strong connection between transformational leadership styles and employees' commitment. Of particular importance is that the general notion of transformational leaders in enhancing employees' organizational commitment will in turn create loyalty and reduce turnover among employees (Rayton, 2006). Dunn, Dastoor, \& Sims, (2012) conducted study in US and Israel organization revealed that transformational leadership has impact on organization commitment. Transformational leadership develops interpersonal relationship between the supervisor and employees to achieve the high level of commitment Bushra, Usman, and Naveed (2011) study completed in health sector in Singapore by Avolio et al. (2004) transactional leadership has positive relationship with commitment. Transformational leadership is has ability to influence employees commitment (Limsili and Ogunlana, 2008, Ismail and Yusuf 2009; Jo0, Jun Yoon, \& Jeung, 2012 Ali, Jan, Ali, \& Tariq, 2014). According to the Clark et al., (2009) conducted study hostels that empowerment in leadership styles can create transformational climates that can in turn promote customer centric culture among the frontline employees. They further suggested that may transformational leadership in particular can enhance employee's CSQ. The same is also supported by (Hashim \& Mahmood, 2012, 2011). Based on the above evidence from the literature it is evident that transformational leadership can potentially contribute to CSQ, therefore following hypothesis is proposed:

$\mathrm{H} 1$ : There is a positive relationship between transformational leadership style and the medical staff's CSQ

\subsection{Transactional Leadership and CSQ}

In the transactional leadership the leaders provide reward in exchange of performance to subordinates (Burn, 1978) the leaders and followers bargain to settle the goals and output performance (Hartog, Muijien \& Koopman, 1997). The progressions made are seen as rewards which are exchange for satisfying these alluring contractual commitments.

Transactional leaders give importance to exchange relationship between followers and leaders whereby leader is fully willing to fulfill the follower's needs in exchange for their performance to meet objective of organization (Jabnoun \& Rasasi, 2005). According to Chen, (2004) transactional leadership can work better in a supportive and bureaucratic culture which inspires their followers' toward commitment to the organization. In most cases the transactional leaders depend on contingency reward and monitoring of employees performance (Bass, 1997, 1998). Previous research indicates that this type of leadership highly motivates the employees to affirmative organization commitment (Emery \& Barker, 2007). Nguni et al., (2006) it is stated that transactional leadership has ability to inspire organizational commitment among employees.

Past research findings were focused on the relationship between transactional leadership and factors that influence on organizational outcomes such as employees commitments, job satisfaction, or organizational citizenship behavior (Emery \& Barker, 2007; McGuire \& Kennerly, 2006; Judge \& Bono, 2000; Berson \& Linton, 2005 and Nguni et al., 2006). Similarly, numerous studies in the past report that transactional leadership has positive influence over employee commitment (McGuire \& Kennerly 2006; Bess \& Goldman, 2001). On the contrary, studies also report a negative effect of transactional leadership over employee commitment (Montez and Gmelch (2000) and Heck, Johnasrud and Rosser (2000). According to Hasim and Mahmood, 2012) conducted in education sector and involving 387 employees' public and private universities. Result is showing that transactional leadership has link with CSQ and suggesting confirming the relationship in hospital setting. However, there has been lack of focus on the relationship between transactional leadership and CSQ for which literature is very limited. Hence, this study will investigate the relationship between transactional leadership and CSQ.

$\mathrm{H} 2$ : There is a significant positive relationship between transactional leadership style and the medical staff's CSQ

\subsection{Laissez-Fair Leadership and CSQ}

The other leadership style besides transformational and transactional leadership is laissez-faire which is characterized as non-leadership or the absence of leadership (Avolio et al., 1999; Northouse, 2010) they further claimed that this kind of leadership always renounces their liability, delays decisions, gives no feedback and offers less attention to assist subordinates to fulfill their needs. Similarly, Robbins, Judge, \& Sanghi, (2007) and Luthans (2005, p. 562) proposed similar explanation that laissez-faire style is "abdicates responsibilities to avoid making decision".

Antonakis, Avolio, and Sivasubramaniam (2003) suggested that it is considered as the most passive and least effective form of leadership behavior. Apart from that, laissez-faire leaders are considered to be inactive, which is different from the transformational and transactional leaders who are always becoming active leaders (Yammarino \& 
Bass, 1990) and they also uninvolved in the work of the unit. Hence, defending this kind of leadership style is very difficult unless the leader's subordinates are someone who is an expert and well-motivated specialist such as scientists because according to Mondy and Premeaux (1995), laissez-faire leaders always let their group members in making all decisions.

This has been fully supported by Sutermeister 1969; Williams, 1987) who said that the laissez-faire style may be effective in certain environments such as with a group of scientists or college professors.

However, this leadership style has positive influence over many organizational and individual variables for example; Ali \& Ibrahim (2014) reported that laissez-fair leadership style has a positive effect on innovation. Another study showed that laissez-fair leadership style has positive relationship with employee commitment (Sorenson, 2000). Empirically studied conducted on primary school and found affective commitment positively related with the laissez-faire leadership style due to principal not interfere in teachers jobs (Cemaloğlu, Sezgin, \& Kılınç, 2012)

According to Ghorbanian, Bahadori, \& Nejati (2012) this type of leadership plays a crucial role in many professions, especially in challenging positions such as emergency medical service jobs. Although this leadership style is considered as mostly passive leadership style however, in certain cases research report this as a useful leadership style Sutermeister (1969) Williams (1987) Ghorbanian et al., (2012). Hence it is imperative to investigate the relationship of Laissez-fair leadership style with CSQ.

H3: There is a significant positive relationship between Laissez-fair leadership style and medical staff's CSQ.

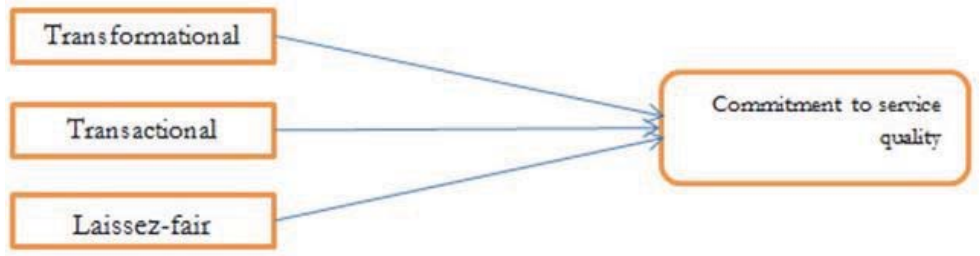

Figure 1 - Proposed Theoretical Framework

\section{Theoretical Foundation of the Study}

The cognitive dissonance theory (Festinger, 1957) explains that the staff, specifically in service organizations, needs to be consistent in their behavior, attitudes as well as beliefs or thought (cognitions). Tosi and Mero (2003) and Morris and Maisto (2009) suggested that when dissonance or inconsistency occur, the employees will try to justify their behavior, thought, or feelings in order to resolve or reduce the discomfort situation that they are experiencing. In accordance with this it is believed that the most convenient way to change their attitude is by reducing the discomfort or dissonance (Morris \& Maisto, 2009). According to dissonance theory, this dissonance situation could be effectively tackled by the leaders; the theory particularly specifies transformational, transactional and Laissez-fair styles of leadership Bass (1990); Burns (1978) William et al., 2007; (Northouse, 2010). (Sutermeister, 1969; Williams, 1987). Hence this investigation is carried out in the light of cognitive dissonance theory.

\section{Methodology}

The quantitative research design was used in this study to investigate the impact of leadership styles on commitment to service quality.

\subsection{Population and sample of the study}

The target population for this study was doctors (medical staff) from public sector hospitals of Sindh province. Total doctors in the Sindh hospitals (www.pmdc.org.pk) comprise a population of 70594. The population of this study covers all public hospitals, mainly located in Sindh Pakistan.

In order to avoid any sampling error, the Krejcie and Morgan (1970) was used to determined sample size. Sample; according to which a minimum of 382 responses were required form the population of 75,000 . Considering the lower response expectations a total of 764 questionnaires were distributed following on the suggestions of Bartlet, Kotrilik. (2001). 


\subsection{Sampling technique}

The population of this study covers all public hospitals, mainly located in Sindh Pakistan. However, Sindh Health department and Health Ministry of Pakistan are the only government regulatory authority for hospitals in the country, but they failed to provide complete lists of medical staff in the province. For this study multi-stage cluster sampling was selected. Under multi-stage sampling at beginning stage sampling was divided into areas, states, districts, or towns (Kothari, 2004; Allen et al., 2002). For the present study in multi-stage cluster sampling, first stage was to select whole Pakistan country than second step was to divide it into four provinces first Punjab second Sindh third NWF and fourth Baluchistan; third step was to select Sindh province out of four provinces. Sindh is divided into four parts. Hence we created four clusters; i.e Karachi, Hyderabad, Larkana and Sukkur and all of these four clusters make up a total population of 75,000 hence all four clusters of Sindh province were selected for present study. And the Unit of analysis for present study is individual doctors (medical staff) of the Sindh province, Pakistan.

\subsection{Instrumentation and data collection procedure}

For measuring leadership transformational, transactional and Laissez-fair leadership styles the multifactor leadership questionnaire (MLQ 5x-short form) from the work of (Bass, 1985) was used. The MLQ originally consists of 45-items following (Boehnke et al, 2003; Antonakis et al, 2003) 36-items have been used for the present study.

For the purpose of measuring CSQ the modified version of CSQ suggested by (Clark, et al., 2009) with 9-itmes was used for this study, which was originally developed by Mowday, Steers, and Porter (1979). The five point likert scale with 5 strongly agree and 1 strongly disagree has been used. The survey method was used for data collection from the 43 hospitals of Sindh Province, Pakistan.

\section{Data Analysis Method}

\subsection{Structural Equation Modeling Approach}

Present study used Smart PLS.2 software for structure equation modeling (SEM) (Ringle et.al 2005). In smart PLS there are two models, measurement and structural model. These methods are used to examine the individual item reliability, internal consistency reliability, convergent validity, discriminant validity, significance of path coefficients, level of R-square values. According to Chinomona and surujal, 2012 that Smart PLS is most power full approach for measuring the causal relationship between variables containing multiple constructs and indicators. Smart PLS has ability to handle large to small sample size. Looking into these features and benefits of SmartPLS, it has been used for data analysis in the present study. In respect, for resampling used bootstrapping method to test statically significance of variables relationship.

\section{Results}

\subsection{Demographic profile}

The table 1 present profile of respondents. The participants were asked of demographic information contains gender, martial status, age, education level, services. The number of male respondent $55.2 \%$ was found slightly higher than female $44.8 \%$. Marital status single respondents $47.3 \%$ and married $52.7 \%$. From the age perspective, most of the respondents were of middle age 20 to 30 years $61.5 \%$ and second highest age group was 30 to 40 years with $26.8 \%$. In between 40 to 50 years the respondents were $10.4 \%$ and for 50 to 60 years there was only $1.3 \%$. The majority of the respondents $64.7 \%$ were having MBBS, whereas participating holding FPCS were $7.3 \%$, and $3.8 \%$ were PhD holders and $24.3 \%$ were having educational degree. In terms of length of service medical staff were having 1 to 5 years' work experience, $37.5 \%$ had less than one year work experience, $32.2 \%$ had 5 to 10 years work experience, $23 \%$ staff with 10 15 years' experience was $5.7 \%$ and $2.5 \%$ were having 15 years and more work experience. 
Table 1: The respondent's demographics

Demographic characteristic description of the study

\begin{tabular}{|c|c|c|c|}
\hline & & Frequency & Percentage \\
\hline \multirow{2}{*}{ Gender } & Male & 175 & $55.2 \%$ \\
\hline & Female & 142 & 44.8 \\
\hline \multirow{2}{*}{ Marital status } & Single & 150 & 47.3 \\
\hline & Married & 167 & 52.7 \\
\hline \multirow{4}{*}{ Age } & 20-30Years & 195 & 61.5 \\
\hline & 30-40years & 85 & 26.8 \\
\hline & 40-50ears & 33 & 10.4 \\
\hline & 50-60years & 4 & 1.3 \\
\hline \multirow{4}{*}{ Education level } & Specialist doctors (PhD holders) & 12 & 3.8 \\
\hline & FCPS & 23 & 7.3 \\
\hline & Doctor MBBS & 205 & 64.7 \\
\hline & Other educational degrees & 77 & 24.3 \\
\hline \multirow{5}{*}{ Services } & Less than one year & 99 & 31.2 \\
\hline & 1 to 5 years & 199 & 37.5 \\
\hline & 5 to 10 years & 73 & 23 \\
\hline & 10 to 15 years & 18 & 5.7 \\
\hline & More than 15 years. & 8 & 2.5 \\
\hline
\end{tabular}

\section{Measurement Model}

For determining the psychometric properties of the scales first, the individual item reliability was examined using outer loadings of each of the measures of each construct (Hair, Hult, Ringle, \& Sarstedt, 2014; Hulland, 1999). As a rule of thumb the loadings 0.50 and above were retained (Barclay, Thompson, \& Higgins, 1995; Chin, 1998) the loadings below the threshold of .50 were deleted in the present study. As can be seen table 2 all items loadings not less than 0.5 (ranged 0.94 to 0.53 ) therefore all on acceptable level.

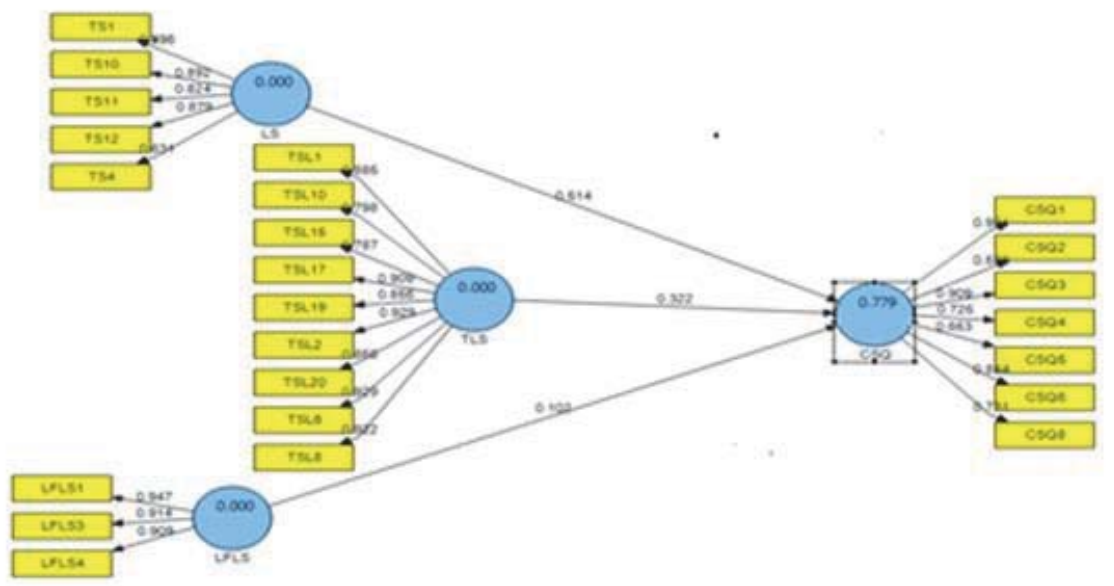

Figure 2: The measurement mode 
Table 2: Result of measurement model

\begin{tabular}{|c|c|c|c|c|c|}
\hline Latent variable & Items & Loadings & R-Square Value & AVEVALUE & CR VALUE \\
\hline \multirow[t]{9}{*}{$\begin{array}{l}\text { Transformationa } \\
\text { I leadership }\end{array}$} & TSL1 & 0.884883 & \multirow{9}{*}{000} & \multirow{9}{*}{0.769767} & \multirow{9}{*}{0.967731} \\
\hline & TSL10 & 0.798323 & & & \\
\hline & TSL15 & 0.787351 & & & \\
\hline & TSL17 & 0.909002 & & & \\
\hline & TSL19 & 0.855611 & & & \\
\hline & TSL2 & 0.928889 & & & \\
\hline & TSL20 & 0.867853 & & & \\
\hline & TSL6 & 0.928889 & & & \\
\hline & TSL8 & 0.922200 & & & \\
\hline \multirow[t]{5}{*}{$\begin{array}{l}\text { Transactional } \\
\text { leadership }\end{array}$} & TS1 & 0.596766 & \multirow{5}{*}{000} & \multirow{5}{*}{0.560622} & \multirow{5}{*}{0.856591} \\
\hline & TS10 & 0.891884 & & & \\
\hline & TS11 & 0.824349 & & & \\
\hline & TS12 & 0.879176 & & & \\
\hline & TS4 & 0.631283 & & & \\
\hline \multirow[t]{3}{*}{ Laissez-fair } & LFLS1 & 0.947336 & \multirow{3}{*}{000} & \multirow{3}{*}{0.852737} & \multirow{3}{*}{0.945551} \\
\hline & LFLS3 & 0.913875 & & & \\
\hline & LFLS4 & 0.908624 & & & \\
\hline \multirow[t]{7}{*}{$\begin{array}{l}\text { Commitment to } \\
\text { service quality }\end{array}$} & CSQ1 & 0.921037 & \multirow{7}{*}{0.779} & \multirow{7}{*}{0.594332} & \multirow{7}{*}{0.908778} \\
\hline & CSQ2 & 0.535953 & & & \\
\hline & CSQ3 & 0.909019 & & & \\
\hline & CSQ4 & 0.725219 & & & \\
\hline & CSQ5 & 0.652538 & & & \\
\hline & CSQ6 & 0.84392 & & & \\
\hline & CSQ8 & 0.731099 & & & \\
\hline
\end{tabular}

The composite reliability coefficient was employed for ascertaining the internal consistency reliability of the measures used in this study. Based on the rule of thumb (Bagozzi and Yi, 1988; and Hair et al., 2011, Chin 1998) the composite reliability coefficient should be .70 or more. Table 2 shows the composite reliability coefficient of the latent constructs ranged from .856 to .967 which is above than the minimum acceptable level of .70 indicating that the measures used in present study have adequate level of internal consistency reliability. Accrding to Chin (1998) average variance extracted (AVE) should be more than 0.5. Table 2, is showing that AVE from 852 to 560 respectively, results reveal that AVE is acceptable in present study. Further table 3, the average variance extracted (AVE) was used to ascertain discriminant validity (Fornell \& Larcker, 1981). For achieving adequate level of discriminant validity Fornell and Larcker have further suggested that the square root of AVE should be greater than the corrections among latent variables. 
Table 3: Discriminatory validity of constructs

\begin{tabular}{lcccc}
\hline Latent Variable Correlations & & & & \\
\hline & CSQ & LFLS & LS & TLS \\
CSQ & 0.7750929 & & & \\
laissez-fair & 0.771379 & 0.923438 & & \\
Transactional & 0.73209 & 0.700324 & 0.748747 & \\
Transformational & 0.712769 & 0.800535 & 0.735667 & 0.877364 \\
\hline
\end{tabular}

The entries represent the correlation and other one square root of average variance.

Table 3 shows that the square roots of AVEs were greater than the correlations among latent variables, which indicates the existence of adequate discriminant validity.

\section{Structure Model}

In order to determine the significance of the path coefficients the standard bootstrapping with a number of 5000 bootstrap samples and 317 cases was applied (Hair, Sarstedt, Ringle, \& Mena, 2012; Henseler, Ringle, \& Sinkovics, 2009). The significant paths of the research model are presented in Table 4 and figure 3 respectively.

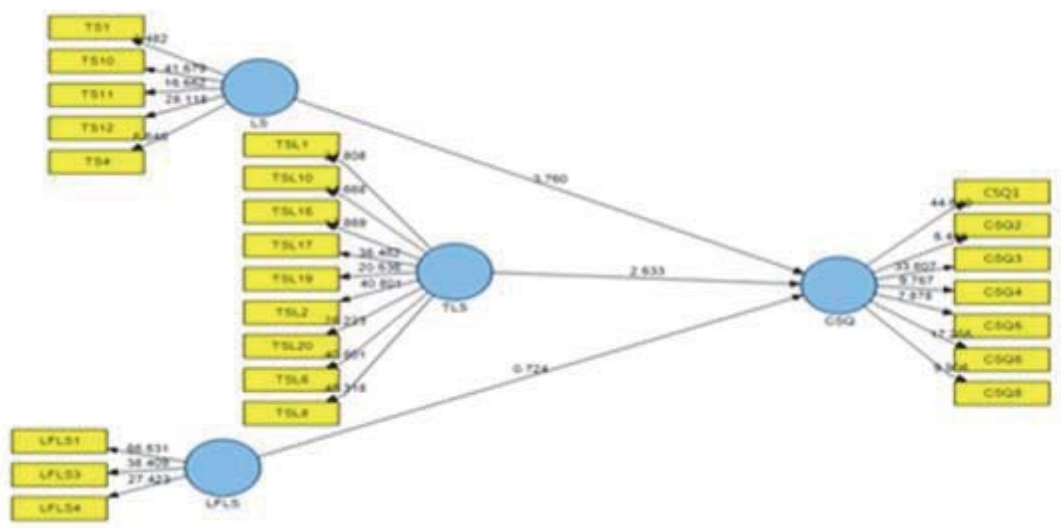

Figure 3: The structure mode

The results reveals in Figure 3, that influence of transformational leadership (TSL) transactional leadership (TS) and laissez-fair leadership (LFLS) on commitment to service quality. Results of figure 3 showing that transformational leadership has positive significant relationship with CSQ is (Beta 0.321 (t-value=2.53). Therefore, H1 is supported. Regarding TS influence on CSQ, results showing that TS has positive relationship with CSQ (Beta is 0.514 (tvalue=3.75). Therefore, there is positive relationship which supports $\mathrm{H} 2$. However, $\mathrm{H} 3$ is not supported because the path coefficient from Laissez-fair to CSQ is not significant (Beta is $t=0.102227$ ( $\mathrm{t}$-value $=0.723602$ ). findings of study support two hypotheses is proved and TSL and TS has positive relationship with CSQ. However third hypothesis is rejected LFLS has insignificant relationship with CSQ.

Table 4: Results of Structural Equation Model Analysis

\begin{tabular}{cccccl}
\hline Hypothis & Relation & Beta & SE & T -Statistics & Result \\
\hline H1 & TLS $>$ CSQ & 0.321736 & 0.127007 & 2.533218 & Supported \\
H2 & TL>COS & 0.514281 & 0.136795 & 3.759508 & Supported \\
H3 & LFLS>CSQ & 0.102227 & 0.141275 & 0.723602 & Not supported \\
\hline
\end{tabular}

Note: TSL, Transformational leadership, TL, Transactional leadership, LFLS, Laissez-faire 
Meanwhile the results of the present study report $0.779 \mathrm{R}^{2}$ which suggests that together transformational, transactional and laissez-fair leadership style these variables explain $0.779 \%$ of variance in the dependent variable.

\section{Discussion}

The results of the study support that the transformational leadership is positively associated with CSQ. This is consistent with the argument of (Hasim and Mahmood, 2011) who stated that transformational has potential influence on CSQ. It is imperative from the findings that transformational leadership has potential ability to influence the attitudes of subordinates; that ultimately leads them towards becoming committed to quality of service they provide to customers. Apart from these findings it is also evident in the literature of transformational leadership that it has potential influence on affective commitment. (Clark, et al 2009) focused the hotel industry who argued that may transformational leadership more influence on commitment to service quality and transformational leadership style ideal for direct service deliver employees. Hashim \& Mahmood, (2012) conducted study in education sector academic staff to result revealed that transformational leadership has relationship with CSQ. Other literature also supports the positive link between commitment and subordinate commitment to service quality. Rowold, Borgmann, \& Bormann, (2014) found that transformational leadership style has strong significant influence on affective commitment further, (Barnett et al., 2001; Erkutlu, 2006; Emery \& Barker, 2007; Liao \& Chuang, 2007). Further, Wallace et al., (2013) stated that the leadership can encourage employees towards commitment. Avolio et al. (2004) conducted a study on staff nurses in a public hospital of Singapore and stated that transformational leadership positively affects organizational commitment. Ismail and Yusuf (2009) studied the impact of transformational leadership on followers' commitment. Clearly these findings transformational leadership has relationship with subordinates CSQ. Correspondingly, effects of transformational leadership from public hospital of Sindh would be similar.

Second hypothesized of present study the transactional leadership is positive related to commitment to service quality. Results of present study line with (Hashim, \& Mahmood, 2012; Jamaludin, Hashim, \& Mahmood 2015) transactional leadership style has positive relationship with CSQ. Further previous study is supporting result. McGuire Kennerly's (2006) conducted study in health care services and Nguni et al., (2006) conducted in service sector in education findings of these studies transactional leadership related to affective commitment. Previous scholar argued that transactional leadership has supportive and bureaucratic cultures particularly in service organization (Emery \& Barker, 2007; Chen, 2004; Bajunid, 2008). Emery \& Barker, (2007) stated that transactional leader has ability to motivate employees towards a commitment of service in bureaucratic nature and argued that this type of leadership style to motivate staff high organization commitment.

On the contrary, our results show that the laissez-faire style of leadership has no significant relationship with CSQ. The examination of the relationship between laissez-faire style of leadership and CSQ was merely carried out referring the suggestions from the work of (Sutermeister 1969; Williams, 1987; and Ali \& Ibrahim, 2014), who proposed that variables could have significant impact in the specific settings like hospital services and education services and scientist work as this type of leadership has important role in different situation. But findings of present study have no significant relationship with commitment to service quality. Our study findings are in line with Zareen, Razzaq, Mujtaba, 2014; Chaudhry, \& Javed, 2012) who argued that Laissez-fair leadership style was not important to motivate employees to perform at high level as compare to transformational and transitional leadership. The leaders who adopt the laissez-fair leadership will not produce strong employee's commitment or may be negative outcomes. Bučiūnienė and Škudienė (2008) argued that laissez-faire leadership style mostly negatively related and insignificant with commitment of employees.

Present study found that transformational leadership has more influence on commitment to service quality in public hospital of Sindh Pakistan as compare to transactional leadership and laissez-fare leadership style. However, it does not mean that the transactional and laissez-fair leadership styles are of no use. Dominantly, the findings supports the roles of transformational and transactional leadership stating their potential ability to influence the medical staff toward commitment to service quality on their own initiative for public hospital of Sindh, Pakistan.

\section{Conclusion}

The results of the present study have extended the literature on cognitive dissonance theory by explaining the potential link between transformation, transactional and CSQ. However, it is evident from the results that the laissez-faire style of leadership does not potentially influence CSQ. Besides contributing to the cognitive dissonance theory, the study also potentially proved to be multidisciplinary by combining the organizational behavior and service quality management. 
In specific, it might be difficult for public hospitals of Sindh to achieve performance and customer satisfaction goals by delivering best services without the appropriate selection of the leadership style. This research was effort to start in most abandoned research settings but empirical study are anticipated to deliver important information to implications for practitioners and academicians. As this investigation was merely conducted in the public sector hospitals of Sindh province in Pakistan therefore it is suggested that the leaders in those hospitals need to further inhibit the behaviors that are in line with transformational and transactional leadership styles to bring in a positive change in the employee attitudes towards CSQ. Although, the results of the study have proved valuable in extending the literature on cognitive dissonance theory and at the same time have offered valuable inputs to practitioners and academicians.

For practitioners the present study offers valuable insights; Organizations must adopt the transformational and transactional leadership style leading the medical staff to obtain employee commitment toward service quality in organization. Leaders should set tone that influences medical staff for betterment of their hospitals. On academic perspective, present study is contributing to leadership style literature by investigating influence of leadership style on commitment to service quality line with diverse organizations with a particular focus on the hospital industry. The finding of study reveals that leadership style is significant in hospitals and boost employee commitment toward service quality.

However the study is not without the limitations. First, the participants in the study were from public sector hospitals of Sindh province therefore the generalizations on the country basis is difficult, hence it is suggested to further validate this study into private sector of Sindh province and into other parts of the country as well. Second, the data was collected in one point in time therefore a longitudinal study could further confirm these findings. Lastly, there could be possibility of the social desirability in the results therefore future researcher could use alternative strategies for reducing social desirability.

\section{References}

Ali, A. Y. S., \& Ibrahim, I. H. (2014). The Impact of Leadership Style on Corporate Innovation: Survey from Telecommunication Industry in Somalia.

Ali, N., Jan, S., Ali, A., \& Tariq, M. (2014). Transformational and Transactional Leadership as Predictors of Job Satisfaction, Commitment, Perceived Performance and Turnover Intention (Empirical Evidence from Malakand Division, Pakistan). Life Science Journal, 11(5), 48-53.

Allen, M., Kilpatrick, D., Armstrong, M., Briggs, R., Course, G., \& Pérez, N. (2002). Multistage cluster sampling design and optimal sample sizes for estimation of fish discards from commercial trawlers. Fisheries Research, 55(1), 11-24.

Antonakis, J., Avolio, B. J., \& Sivasubramaniam, N. (2003). Context and leadership: An examination of the nine-factor full-range leadership theory using the Multifactor Leadership Questionnaire. The leadership quarterly, 14(3), 261-295.

Ashill, N. J., Ragheb, M. A., Abd-El-Salam, E. M., \& El-Samadicy, A. (2014). Antecedents and consequences of management commitment to service quality. The Business \& Management Review, 4(4), 24.

Ashill, N.J., Carruthers, J., \& Krisjanous, J. (2006). The effect of management commitment to service quality on frontline employees' affective and performance outcomes: An empirical investigation of New Zealand public healthcare sector. Int. j. Nonprofit volunt. sect. Mark. wiley interscience, 11, 271-287.

Avolio, B.J. (1999) Full Leadership Development: Building the Vital Forces in Organizations. Thousand Oaks: Sage.

Avolio, B. J., Zhu, W., Koh, W., \& Bhatia, P. (2004). Transformational leadership and organizational commitment: mediating role of psychological empowerment and moderating role of structural distance. Journal of Organizational Behaviour, 25, 951-968..

Babakus, E., Yavas, U., Karatepe, 0.M., \& Avci, T. (2003). The effect of management commitment to service quality on employees' affective and performance outcomes. Journal of the Academy of Marketing Science, 31, 272-286.

Bagozzi, R. P., \& Yi, Y. (1988). On the evaluation of structural equation models.Journal of the academy of marketing science, 16(1), 7494.

Bajunid, I.A. (2008). The development of educational leaders in Malaysia: The creation of a professional community. In D. Johnson \& R. Maclean (Ed); Teaching: Professionalization , Development and Leadership.(pp. 215-232). United States of America: Springer Science \& Business Media.

Barclay, D., Higgins, C., \& Thompson, R. (1995). The partial least squares (PLS) approach to causal modeling: Personal computer adoption and use as an illustration. Technology studies, 2(2), 285-309.

Barling, J., Moutinho, S. and Kelloway, E.K. (2000), "Transformational leadership and group performance: the mediating role of affective commitment", Working Papers:

Barnett Kirn, Hi., Tavitiyaman P., \& Kim, W.G. (2009). The effect of management to service on employee service behaviours : The mediation effect of job satisfaction. Journal of Hospitality \& Tourism Research, 33, 369-390.

Barnett, K., McCormick, J., \& Conners, R. (2001). Transformational leadership in schools: Panacea, placebo or problem? Journal of Education Administration, 39, 24-46.

Bass, B.M (1985a) leadership and performance beyond expectation. New Yark: Haper.

Bass, B.M (1985b) leadership Good, better, best, Organization Dynamics, 3,26- 40.

Bass, B.M. (1997). Does the transactional transformational paradigm transcend organizational and national boundaries? American 
Psychologist, 52,130-139.

Bass, B.M. (1998). Transformational leadership: industry, military, and educational impact. NEW Jersey: Erlbaaum.

Bass, B.M. (1999), "Two decades of research and development on transformational leadership", European Journal of Work and Organizational Psychology, Vol. 8 No. 1, pp. 9-32.

Berson, Y., \& Linton, J. D. (2005). An examination of the relationships between leadership style, quality, and employee satisfaction in R\&D versus administrative environments. $R \& D$ Management, 35(1), 51-60.

Bess, J. L., \& Goldman, P. (2001). Leadership ambiguity in universities and K-12 schools and the limits of contemporary leadership theory. The Leadership Quarterly, 12, 419-450.

Bitner, M.J., Booms, B.H., and Tetreault, M.S. (1990), 'The Service Encounter: Diagnosing Favorable and Unfavorable Incidents', Journal of Marketing, 54, 1, 71-84.

Boehnke, K., Bontis, N., DiStefano, J.J., \& DiStefano, A.C. (2003). Transformational leadership: An examinantion of cross differences and similarities. Leadership \& Organization Development Journal, 24, 5-15.

Bowen, D.E., and Schneider, B. (1988), 'Service Marketing and Management: Implications for Organizational Behavior,' Research in Organizational Behaviour, 10, 43-80.

Bowen, D.E., Siehl, C., \& Schneider, B. (1989). A framework for analyzing customer service orientations in manufacturing. Academy of Management Review, 14, 75-95.

Bartlet, J.E., \& Kotrilik.J.W. (2001) Organization Research: Determined approach sample size in survey Research Information Technology, Learning and Performance Journal 19 (1), 43-50.

Bučiūnienè, I. \& Škudienè, V. (2008). Impact of Leadership Styles on Employees' Organizational Commitment in Lithuanian Manufacturing Companies, SEE Journal, 33, 57-65.

Burns, J.M. (1978). Leadership. New York: Harper \& Row.

Bushra, F., Usman, A., \& Naveed, A. (2011). Effect of transformational leadership on employees' job satisfaction and organizational commitment in banking sector of Lahore (Pakistan). International journal of Business and Social science, 2(18), 261-267.

Cemaloğlu, N., Sezgin, F., \& Kılınç, A. (2012). Examining the relationships between school principals' transformational and transactional leadership styles and teachers' organizational commitment. The Online Journal Of New Horizons In Education, 2(2), 53-64.

Chaudhry, A. Q., \& Javed, H. (2012). Impact of transactional and laissez faire leadership style on motivation. International Journal of Business and Social Science, 3(7), 258-264.

Chen, L.Y. (2004). Examining the effect of organization culture and leadership behaviours on organizational commitment, job satisfaction, and job performance at small and middle-sized firms of Taiwan. The Journal of American Academy of Business, Cambridge, 5, 232-438.

Chin, W. W. (1998). The partial least squares approach to structural equation modeling. Modern methods for business research, 295(2), 295-336.

Chinomona, R \& Surujal, B. 2012. The influence of student internship work experience on their self-improvement and professionalism in Sport Management. African Journal for Physical, Health Education, Recreation and Dance, 18(4): 885-899.

Clark, R.A., Hartline, M.D., \& Jones, K.C. (2009). The effects of leadership style on hotel employees' commitment to service quality. Cornell Hospitality Quarterly, 1-23.

Cole, R., Barcdayan, P. and White, B. (1993), "Quality, participation and competitiveness", California Management Review, Vol. 35 No. 3, pp. 68-81.

Dale, B.G. and Duncalf, A.J. (1984), "Quality-related decision making: a study in six British companies", International Journal of Operations \& Production Management, Vol. 5 No. 1,pp. 15-25.

Dunn, M. W., Dastoor, B., \& Sims, R. L. (2012). Transformational leadership and organizational commitment: A cross-cultural perspective. Journal of Multidisciplinary Research, 4(1), 45.

Ebrahimpour, M. (1985), "An examination of quality management in Japan: implications for management in the United States", Journal of Operations Management, Vol. 5 No. 4, pp. 419-31.

Elmadag, A.B., Effinger, A.E., \& Franke, G.R. (2008). Antecedents and consequences of frontline service employee commitment to service quality. Journal of Marketing Theory and Practice, 16, 95-110.

Emery, C.R., \& Barker, K.J. (2007). The effect of transactional and transformational leadership styles on the organisational commitment and job satisfaction on customer contact personnel. Journal of Organisational Culture, Communication and Conflict, 11, 77-90.

Erkutlu, H. (2006). The impact of transformational leadership on organisational and leadership effectiveness. Journal of Management Development , 27, 708-726.

Eunyoung, K. (2007). Transformational leadership. Encyclopedia of Educational Leadership and Administration , [Web document],1 page. Available: http://sage creference.comiedleadership/Article-n.575.html [2008, 14 Febuary].

Festinger, L. (1957). A Theory of Cognitive Dissonance. Stanford, CA: University of Stanford Press.

Fornell, C., \& Larcker, D. F. (1981). Structural equation models with unobservable variables and measurement error: Algebra and statistics. Journal of marketing research, 382-388.

Geijsel, F., Sleegers, P., Leithwood, K., \& Jantzi, J. (2003). Transformational leadership effects on teachers' commitment and effort toward school reform. Journal of Educational Administration, 41,228-256.

George, W.R., and Gronroos, C. (1989), 'Developing Customer-Conscientious Employees at Every Level: Internal Marketing,' in Handbook of Service Marketing, eds. Carole A. Congram and Margaret L. Friedman, New York: AMACOM, pp. 85-100.

Ghorbani, M., Alemorad, M., \& Bojnord, B. B. (2013). Study of the Relationship Between Management Commitment to Service Quality 
(MCSQ) a0nd Services Receiving Performance in Public and Private Hospitals. World Applied Sciences Journal, 21(8), 11671175.

Ghorbanian, A., Bahadori, M., \& Nejati, M. (2012). The relationship between managers' leadership styles and emergency medical technicians' job satisfaction. The Australasian medical journal, 5(1), 1.

Ghorbanian, A., Bahadori, M., \& Nejati, M. (2012). The relationship between managers' leadership styles and emergency medical technicians' job satisfaction. The Australasian medical journal, 5(1), 1.

Hair, J. F., Ringle, C. M., \& Sarstedt, M. (2011). PLS-SEM: Indeed a silver bullet. Journal of Marketing Theory and Practice, 19(2), 139152.

Hair, J. F., Hult, G. T. M., Ringle, C. M., \& Sarstedt, M. (2014) A Primer on Partial Least Squares Structural Equation Modeling (PLSSEM). Sage, Thousand Oaks, CA

Hair Jr, J. F., Hult, G. T. M., Ringle, C., \& Sarstedt, M. (2013). A primer on partial least squares structural equation modeling (PLS-SEM). Sage Publications.

Hair, J. F. W.C Black, B.J Babin and R. E Anderson (2010). Multivariate data analysis. $7^{\text {th }}$ edition, prentice hall, Upper Saddle River, New Jersey.

Hair, J. F., Sarstedt, M., Ringle, C. M., \& Mena, J. A. (2012). An assessment of the use of partial least squares structural equation modeling in marketing research. Journal of the Academy of Marketing Science, 40(3), 414-433.

Hartline, M.D, Maxham III, 1G., \& McKee, D.O. (2000). Corridors of influence in the dissemination of customer-oriented strategy to customer contact service employees. Journal of Marketing, 64,35-50.

Hartline, M.D., and Ferrell, O.C. (1996), 'The Management of Customer-Contact Service Employees: An Empirical Investigation,' Journal of Marketing, 60, October, 52-70.

Hartog, N.D.N., Muijen, V., \& Koopman, P.L. (1997). Transactional versus transformational leadership: An analysis of the MLQ. Journal of Occupational and Organizational Psychology, 70, 19-34. Hashim, R. A., \& Mahmood, R. (2012). how do our Malaysian academic staff perceive their leader's leadership styles in relation to their commitment to service quality?

Hashim, R. A., \& Mahmood, R. (2011)Transformational Leadership Style and Academic Staffs' Commitment to Service Quality at Malaysian Universities.

Hater, J.J. and Bass, B.M. (1988), "Superiors' evaluations and subordinates' perceptions of transformational and transactional leadership", Journal of Applied Psychology, Vol. 73 No. 4, pp. 695-702.

Heck, R.H., Johnasrud, L.K., \& Rosser, V.J. (2000). Administrative effectiveness in higher education: Improving assessment procedures. Research in Higher Education , 41, 663-684.

Henseler, J., Ringle, C. M., \& Sinkovics, R. R. (2009). The use of partial least squares path modeling in international marketing. Advances in International Marketing (AIM), 20, 277-320.

Hulland, J. (1999). Use of partial least squares (PLS) in strategic management research: A review of four recent studies. Strategic management journal, 20(2), 195-204.

Irfan, S. M., \& ljaz, A. (2011). Comparison of service quality between private and public hospitals: Empirical evidences from Pakistan. Journal of Quality and Technology Management, 7(1), 1-22.

Ismail, A., \& Yusuf, M. H. (2009). The relationship between transformational leadership, empowerment and organizational commitment: a mediating test model testing. Journal of Economics, 2(6).

Jabnoun, N., \& Rasasi A.J. (2005). Transformational leadership and service quality in UAE hospitals. Managing Quality Service Journal, $15,70-81$.

Jamaludin, A., Hashim, R. A., \& Mahmood, r. Mediating effect of job satisfaction on transactional leaders and commitment to service quality in malaysian universities.

Joo, Jun Yoon, \& Jeung, (2012). The effects of core self-evaluations and transformational leadership on organizational commitment.Leadership \& Organization Development Journal, 33(6), 564-582.

Judge, T.A. \& Bono, J.E. (2000). Five factor model of personality and transformational leadership. Journal of Applied Psychology, 85, 751-765.

Juran, J.A. (1989), Juran on Leadership for Quality, Free Press, New York, NY.

Karatepe, O. M., \& Karadas, G. (2012). The effect of management commitment to service quality on job embeddedness and performance outcomes. Journal of Business Economics and Management, 13(4), 614-636.

Kothari, C. R. (2004). Research methodology: Methods and techniques. New Age International.

Krantz, K.T. (1989), "How Velcro got hooked on quality", Harvard Business Review, Vol. 67 No. 5, pp. 34-40.

Krejcie, R. V., \& Morgan, D. W. (1970). Determining sample size for research activities. Educational and psychological measurement, 30(3), 607-610.

Lascelles, D.M. and Dale, B.G. (1989), "The buyer- supplier relationship in total quality management", Journal of Purchasing and Materials Management, Vol. 25 No. 2, pp. 10-19.

Deming, W.E. (1986), Out of the Crises, MIT Press, Cambridge, MA.

Lau, E. K. W. (2014). Antecedents of Empowerment and Commitment to Service Quality in the Chinese Hotel Industry. In Knowledge Management in Organizations (pp. 90-98). Springer International Publishing.

Liao, H., \& Chuang, A. (2007). Transforming - service employees and climate: A multilevel, multisource examination of transformational leadership in building long-term service relationship. Journal of Applied Psychology, 92,1006-1019.

Limsili, K., \& Ogunlana, S. O. (2008). Performance and leadership outcome correlates of leadership styles and subordinate commitment. 
Engineering, Construction and Architectural Management, 15(2), 164-184.

Little, M.M., \& Dean, A.M. (2006). Links between service climate, employee commitment and employees' service quality capability. Managing Service Quality, 16, 460-476.

Long, C. S., \& Thean, L. Y. (2011) Relationship between leadership styles, Job satisfaction and employees' Turnover intention: A literature review. Research journal of business management, 5 (3), 91-100.

Lowe, K.B., Kroeck, K.G. and Sivasubramaniam, N. (1996), "Effectiveness correlates of transformational and transactional leadership: a meta-analytic review of the MLQ literature", Leadership Quarterly, Vol. 7 No. 3, pp. 385-425.

Luthans, F. (2005).Organizational Behavior (10thed.).McGraw - Hill/ Irwin Publication.

Malhorta \& Mukherjee. (2004). The relative influence of organizational commitment and job satisfaction on service quality of customer contact employees in banking call centers. Journal of Services Marketing, 18,162-174.

Meyer, J.P. and Allen, C.A. (1991). A three component conceptualisation of organisational commitment. Human Resources Management Review. 1, 61-98.

McGuire, E., \& Kennerly, S.M. (2006). Nurse managers as transformational and transactional leaders. Nursing Economics, 24, $179-185$.

Mitchell, C. (2002). Selling the brand inside. Harvard Business Review, 5-11.

Mondy, R. W., \& Premeaux, S. R. (1995). Management (7th ed.). Englewood-Cliffs-New Jersey: Prentice-Hall.

Morris, C.G., \& Maisto, A.A. (2009). Understanding Psychology. New Jersey: Pearson Edu. Inc.

Mowday, R., Steers, R. \& Porter, L. (1979). The measurement of organisational commitment . Journal of Vocational Behaviour , 14,224227.

Natasha, D., \& Subroto, B. (2003). Effects of management commitment on service quality to increase customer satisfaction of domestic airlines in Indonesia. Singapore Management Review , 25, 85-102.

Nawaz, M. M., \& Bodla, M. A. (2010). Comparative study of full range leadership model among faculty members in public and private sector higher education institutes and universities. International Journal of Business and Management,5(4), p208.

Nguni, S., Sleegers, P., \& Denessen, E. (2006). Transformational and transactional leadership effects on teachers' job satisfaction, organizational commitment, and organizational citizenship behaviour in primary schools: The Tanzanian case. School Effectiveness and School Improvement, 17, 145- 177.

Northouse, P.G. (2010). Leadership: Theory and Practice. (5th ed.) London: Sage.

Organizational Behaviour/Industrial Relations, No. 2000-07, School of Business, Queen'sUniversity, Kingston.

Peccei, R., and Rosenthal, P. (1997), 'The Antecedent of Employee Commitment to Customer Service: Evidence from a UK Service Context,' International Journal of Human Resource Management, 8, 1, 66-86.

Peccei, R., and Rosenthal, P. (2000), 'Frontline Responses to Customer Orientation Programs: A Theoretical and Empirical Analysis,' Human Resource Management, 11, 3, 562-590.

Ringle, C. M. Wende, S \& Will, A. 2005. Smart PLS 2.0 M3. Available at http://www.smartpls.de.

Rayton, B.A. (2006). Examining the interconnection of job satisfaction and organizational commitment: an application of the bivariate probit model. International Journal of Human Resource Management , 17, 139-154.

Reeves, C., \& Hoy, F. (1993). Employee perceptions of management commitment and customer evaluations of quality service in independent firms. Journal of Small Business Management, 31(4), 52.

Robbins, S. P., Judge, T. A. \& Sanghi, S. (2007). Organizational Behavior. (12th ed.). India: Pearson: Prentice Hall.

Rowold, J., Borgmann, L., \& Bormann, K. (2014). Which Leadership Constructs Are Important for Predicting Job Satisfaction, Affective Commitment, and Perceived Job Performance in Profit versus Nonprofit Organizations?. Nonprofit Management and Leadership, 25(2), 147-164

Sergeant, A., and Frenkel, S. (2000), 'When Do Customer Contact Employees Satisfy Customers?' Journal of Service Research, 3, 2, 18-34.

Sorenson, R. L. (2000). The contribution of leadership style and practices to family and business success. Family Business Review, 13(3), 183-200.

Suan, c. I., \& Nasurdin, A. M. (2013). Role clarity, supervisory support, peer support, and work engagement of customer-contact employees in hotels: a future research agenda.Tourismos: An international multidisciplinary journal of tourism, 8(1), 315-329

Sun, P. C., Hsu, W. J., \& Wang, K. C. (2012). Enhancing the commitment to service quality through developmental and rewarding systems: CSQ consistency as a moderator. The International Journal of Human Resource Management, 23(7), $1462-1480$.

Subramony, M., Beehr, T.A., \& Johnson, C.M. (2004). Employee and customer perceptions of service quality in an Indian firm. International Association for Applied Psychology, 53, 311-327.

Sutermeister, R. A. (1969). People and productivity. New York: McGraw-Hill.

To, W. M., Martin, E. F., \& Billy, T. W. (2015). Effect of management commitment to internal marketing on employee work attitude. International Journal of Hospitality Management, 45, 14-21.

Tosi, H.L. \& Mero, N.P. (2003). The Fundamentals of organisational behaviour. Cornwall: Blackwell Publishing.

Wallace, E., de Chernatony, L., \& Buil, I. (2013). Building bank brands: How leadership behavior influences employee commitment. Journal of Business Research, 66(2), 165-171.

Walumbwa, F.O., Orwa, B., Wang, P., \& Lawler, J.J. (2005). Transformational leadership, organizational commitment, Job satisfaction: A comparative study of Kenyan and U.S, Financial Firms. Human Resource Development Quarterly , 16, 235- 256.

Williams, F.K., Ricciardi, D., \& Blackbourn,R. (2007). Theories of Encyclopedia of Educational Leadership and Administration , [Web document],5 pages. Available: http://sage-creference.comiedleadership/Article-n332.html [2008, 14 Febuary]. 
Williams, J. C (1987) human behavior organizations. Cincinnati, OH: South-Western pub.co.

Wolverton, M., Montez, J., \& Gmelch, W. H. (2000, November). The roles and challenges of deans. In ASHE Annual Meeting Paper, Sacramento, CA, November.

Worsfold, P. (1999). HRM, performance, commitment and service quality in the hotel industry. International Journal of Contemporary Hospitality Management, 11, 340- 348.

Yammarino, F. J., \& Bass, B. M. (1990). Transformational leadership and multiple levels of analysis. Human relations, 43(10), 975-995.

Yukl, G. A. 2005. Leadership in organizations (6 $6^{\text {th }}$ ed). Upper Saddle River, NJ: Prentice-Hall.

Zareen, M., Razzaq, K., \& Mujtaba, B. G. (2014). Impact of Transactional, Transformational and Laissez-Faire Leadership Styles on Motivation: A Quantitative Study of Banking Employees in Pakistan. Public Organization Review, 1-19 